\title{
The Question of 'Race' in the Pre-colonial Southern Sahara
}

\author{
BRUCE S. HALL
}

\begin{abstract}
One of the principle issues that divide people in the southern margins of the Sahara Desert is the issue of 'race.' Each of the countries that share this region, from Mauritania to Sudan, has experienced civil violence with racial overtones since achieving independence from colonial rule in the 1950s and 1960s. Today's crisis in Western Sudan is only the latest example. However, very little academic attention has been paid to the issue of 'race' in the region, in large part because southern Saharan racial discourses do not correspond directly to the idea of 'race' in the West. For the outsider, local racial distinctions are often difficult to discern because somatic difference is not the only, and certainly not the most important, basis for racial identities. In this article, I focus on the development of pre-colonial ideas about 'race' in the Hodh, Azawad, and Niger Bend, which today are in Northern Mali and Western Mauritania. The article examines the evolving relationship between North and West Africans along this Sahelian borderland using the writings of Arab travellers, local chroniclers, as well as several specific documents that address the issue of the legitimacy of enslavement of different West African groups. Using primarily the Arabic writings of the Kunta, a politically ascendant Arab group in the area, the paper explores the extent to which discourses of 'race' served growing nomadic power. My argument is that during the nineteenth century, honorable lineages and genealogies came to play an increasingly important role as ideological buttresses to struggles for power amongst nomadic groups and in legitimising domination over sedentary communities. 'Race' was a corollary of the heightened ideological importance of lineage.
\end{abstract}

\section{Introduction}

When the medieval Moroccan traveller Ibn Battuta visited the West African Sahel and Southern Sahara in 1352-53, he brought with him a North African conception of 'racial' difference that appears to have been unfamiliar to the people with whom he interacted. In recounting his travels, Ibn Battuta repeatedly distinguished between three principle types of people found in the area: Blacks, Berbers and Whites. It is clear that those he identified as 'Whites' included only people like himself who originated in North Africa or the Middle East and who resided in the towns of the desert edge, mostly as merchants. With one exception, colour terminology was not used to identify or describe the local Berber-speaking peoples that appear in the text, such as the Massūfa of Walata and Timbuktu, or the Bardāma and Hakkār ${ }^{1}$ of the Southern and Central Sahara. ${ }^{2}$ For Ibn Battuta, the term 'Whites' implied a set

Bruce Hall was awarded a PhD in history from the University of Illinois in 2005. He is currently an Andrew W. Mellon post-doctoral fellow in the Department of History at Johns Hopkins University in Baltimore, Maryland. Email: ouagadoo@yahoo.com

The Journal of North African Studies, Vol.10, No.3-4 (September-December 2005) pp.339-367 
of Arab Muslim cultural practices that those local Berber-speaking peoples, although Muslims, did not share. Scandalised by the freedom Massūfa women enjoyed in their social interactions, and by their matrilineal system of descent, Ibn Battuta compared local Berber speakers to non-Muslims he had visited in South Asia. ${ }^{3}$

The use of colour terminology in marking human difference was not uncommon in medieval North Africa and the Middle East. ${ }^{4}$ It is clear from Ibn Battuta's account of the Berber-speaking peoples whom he met, that his idea of 'race' was primarily based on notions of cultural difference. ${ }^{5}$ Despite descriptions of physical similarities between Berbers and those Ibn Battuta labels, variously, as 'Whites,' Arabs, Moroccans, etc., the Berbers could not be included amongst the 'Whites' because of their distance and foreignness from the normative cultural practices of the Arab Muslim world of Ibn Battuta. As such, it is not surprising that nowhere in Ibn Battuta's text is there any indication that ideas of colour were very prominent in local, Southern Saharan conceptions of identity, if they existed at all. In the fourteenthcentury Sahel and Southern Sahara presented to us here, those that Ibn Battuta identified as Berbers and Blacks appear to have held distinctly local notions of cultural identity that bore little connection to anything we might recognise as 'race'.

By the time that European travellers began to penetrate into the African Sahel in the eighteenth and nineteenth centuries, many of the descendants of the Berberspeaking peoples encountered by Ibn Battuta had developed a much more racialised idea of themselves as 'Whites.' They had adopted many of the trappings of the wider Arab Muslim culture that many now considered themselves to be a part of, including use of the Arabic language and Arab genealogies traced through patrilineal systems of descent. The Arabisation of Berber-speaking populations was certainly never complete, and even many Arabised groups recognised elements of their origins that were Berber. Others, commonly designated as Tuaregs, continued to identify themselves as Berbers, and to speak Berber languages. But, changes in relations with desert-edge 'Black' populations produced a decidedly racialised identity in Arabised and Berber populations alike. Ibn Battuta had described a political situation in which the desert-edge Berbers such as the Massūfa were vassals of the large 'Black' Malian Empire. When the Scottish traveller Mungo Park visited the Hodh region in the border area between present-day Mali and Mauritania in 1796-97, he described a situation of 'Moorish' ${ }^{6}$ domination over 'Blacks.'

[T] he major part of the inhabitants are Negroes, from the borders of the southern states, who prefer a precarious protection under the Moors, which they purchase by a tribute, rather than continue to be exposed to their predatory hostilities. The tribute they pay is considerable; and they manifest towards their Moorish superiors the most unlimited obedience and submission, and are treated by them with the utmost indignity and contempt. ${ }^{7}$

Park reported that the 'Blacks' 'are looked upon by the Moors as an abject race of slaves, and are treated accordingly. ${ }^{8}$ Other European travellers made similar observations. Reporting on his trip down the Niger from Djenné to Timbuktu in 1828, the French traveller René Caillié described the relations between local Tuaregs and 'Blacks' in stark terms: 'The Sourgous 9 [Tuaregs] are a nomad people who live on 
the shores of [the Niger River]; they have the gift of creating fear, and they live at the expense of the unfortunate Blacks, whom they have made into tributaries. ${ }^{10}$ When the German traveller Hienrich Barth passed through the Niger Bend area in 185354 , he noted the degraded condition of local 'Black' people and their fear of the Tuareg, whom he called the 'tormentors' of the 'Blacks.' 11

Like Ibn Battuta, European travellers were deeply influenced by their own conceptions of 'racial' difference, which made them especially sensitive to the distinction between Arab or Berber peoples on the one hand, and 'Blacks' on the other. However, the existence of local ideas about racial difference along the desert edge cannot be so easily dismissed. While certainly distinct from European concepts, there is ample evidence that ideas about 'race' had developed in the Southern Sahara and Sahel in the four hundred and fifty years that separated the accounts of Ibn Battuta and the European travellers. Local intellectuals writing in Arabic had, for centuries, distinguished, at the most basic level, between 'Whites' (bīdān), for those with Arab pedigrees, and 'Blacks' (sūdān). Even a cursory look at the titles of locally authored manuscripts written in the pre-colonial period in the Southern Sahara and Sahel reveals how common such terms of identity were in local literature. ${ }^{12}$ A terminology of colour in local identities is also evident in the spoken languages of the area. In contemporary Hassaniyya Arabic, the language spoken by the Moors (Arabs) of Mauritania and Northern Mali, the terms 'Whites'/'Blacks' (bīdān/sūdān) are used to distinguish between Moors who are, in status, freemen, and those who have a slave past. A different Arabic word for 'Blacks' ( $k w \bar{a} r)$ is used to identify non-Moorish Africans. ${ }^{13}$ In contemporary Tuareg discourse, colour-based terminology is used to distinguish internal social status and to denote those who are termed 'Blacks' (koualnin), whether people of servile origin within Tuareg society, or to refer to non-Tuareg 'Blacks'. ${ }^{14}$ Other Sahelian groups such as the Fulbe use a notion of colour in their categories of identity and status, distinguishing between a 'Red' noble class (wodeebe) and the less noble, or ignoble, 'Blacks' (baleebe). ${ }^{15}$ Likewise, among the traditionally sedentary peoples of the Sahel, notions of colour difference are widespread. In the Niger Bend region for example, the Songhay adjectival suffixes for 'white' (korey) and 'black' (bibi) appear in many place names, among which the best-known example is Sankoré, the name of the famous medieval mosque-university in Timbuktu, whose etymology is from 'White Masters' (san-korey, 'master''white').

The common feature in all of these colour-coded schemes of social status and identity is the negative and servile connotation of blackness. Even in ethnic communities that today are most often considered 'black' by others, and whose members self-identify as such, the idea of blackness was used in the past to refer to their own servile populations. In the Songhay-speaking world of Northern Mali, for example, the idea of blackness was used to designate lower status people, including freed slaves, as 'Blacks' (gaa-bibi, har-bibi). ${ }^{16}$ Historically, the elite stratum of Songhay society did not consider itself to be 'Black.' Today, these labels are rarely used in the Songhay-speaking world, in large part because over the course of the twentieth century, all Songhay speakers came to be designated as 'Blacks' by the colonial administration. Similarly, the usage of the designation 'Blacks' changed 
significantly in Moorish and Tuareg communities during the period of colonial rule. This is most obvious in the case of the Moors, where the term 'sūdann' is now used to refer to Moors who are of slave origin, rather than non-Moorish 'Blacks' who are ethnically and linguistically distinct. ${ }^{17}$ In the pre-colonial Arabic literature of the area, the term 'sūdān' is most often used to refer to 'Blacks' who are ethnically and linguistically distinct from the Moors, and terms of social status such as 'slaves' $(a b \bar{i} d)$ or 'freed slaves' (harätīn) were used to refer to lower status members of Moorish society. It is more difficult to know how the use of the term for 'Blacks' has changed in Tuareg society because in their pre-colonial writings, they used classical Arabic for the most part and adhered to the same local conventions for 'sūdān,' and for lower status members of their own society. One suspects however, that the use of the term for 'Blacks' to refer to low-status members of Tuareg society is, like the Moors, a largely recent development. These changes are in large part the result of European colonial rule that began in the late nineteenth century. Ideas about 'race' gained an increasing importance during the colonial period because of their prominence in the European colonial worldview and because they served the interests of local elites in attempting to maintain their control over servile and slave populations within these desert-edge societies. This is the main reason that social status was increasingly racialised during the colonial period.

There is no question that the impact of European ideas, and more importantly, European power, has been significant in generating racialised discourse among many people in the Sahel ${ }^{18}$ However, it is certainly not the case, as some have argued, that ideas about 'race' were first introduced into this area by Europeans and imposed on people who had no conception whatsoever of racial difference. ${ }^{19}$ Notions of racial difference were very real in the pre-colonial Southern Sahara and Sahel. They were, however, very different from the ideas about 'race' that were later introduced into the area by Europeans. Although a subject that is beyond the scope of this paper, our understanding of the dynamics of racial thinking in this part of Africa today would benefit greatly if we were able to see the dialogical nature of the relationship between local and colonial ideas about 'race,' and the ways that contemporary racial discourse is a product and synthesis of these two very different traditions. To do that however, we require a better idea of local notions of 'race' before the arrival of Europeans than we possess. In what follows, we will explore the intellectual origins of racialised thinking in the Southern Sahara and Sahel, and suggest some of the ways in which local ideas about racial difference developed historically in the pre-colonial period.

\section{Towards a Logic of 'Race' along the Desert Edge}

That people along the desert edge would employ vocabularies of colour to describe themselves and others should, at one level, not be especially surprising since, at a general level, there are clear and easily perceivable phenotypic differences between many Arabophone and Berberophone peoples on the one hand, and those commonly identified as sub-Saharan Africans on the other. There are of course, many exceptions. Certainly for the outsider, it is often very unclear what the correspondence is between 
the various racial identities held by Sahelian people and the actual colour of their skin. Whether or not there are 'objective' physical differences between the different peoples of the desert edge was, however, immaterial to the historical development of ideas about racial difference. ${ }^{20}$ The issue of 'race' in the Southern Sahara and along the desert edge really revolves around how ideas about human difference, whatever their 'objective' validity, were codified in socially significant ways. It is quite likely that perceptions of some kind of physical difference are of great antiquity in the Sahara. The interesting question is not the perception of difference per se, but the ways in which difference was rationalised into larger cultural ideologies that went beyond more or less universal distinctions between Self and Other.

One way of thinking about the types of historical contexts that tend to produce racialised ideologies is to try to unravel the related categories of 'race' and ethnicity. Both race and ethnicity are based on the perception of difference, of the Other. The real conceptual difference between the two is that 'race,' to a much larger extent than ethnicity, has been used to codify social difference. Put another way, 'race' is used to naturalise inequality. Long ago, Max Weber made a distinction between what he called 'caste structure' and 'ethnic coexistence' in his discussion of the different power relations involving people who consider themselves to be ethnically distinct. According to Weber, the 'caste' system is the extreme outcome of differences in social status in a society when these differences between status groups are perceived to be 'ethnic.' Social inequality can be naturalised by racialisation through belief in such things as blood relationships, and as a consequence, exogenous marriage and social intercourse are discouraged. Weber cited the Jews as the paramount historical example of such a racialised 'caste' group. ${ }^{21}$ In his study of ethnic conflict, Donald Horowitz makes a similar distinction between what he calls ranked and non-ranked ethnic systems. In ranked systems, the relations between ethnic groups are hierarchical, with one super-ordinate and the other subordinate. It is in social structures that exhibit the characteristics of Horowitz's 'ranked ethnic systems' that one is most likely to encounter a strong racial component of identity. ${ }^{22}$

Whether or not we want to use the term 'ethnic group' to describe different occupational and linguistic communities along the desert edge in the pre-colonial period, we are at least forced to confront the fact that political relations between these communities changed considerably over time. The southern edge of the Sahara Desert is an ecological and cultural borderland where Saharan Arabo-Berber peoples and subSaharan Africans have interacted over many centuries, producing distinctly Sahelian cultures that share many similar characteristics. Indeed, the vagaries of life in this harsh, drought-prone region made necessary a variety of symbiotic relationships between the traditionally semi-nomadic pastoralists and sedentary agricultural peoples who occupied the area. However, the relations between peoples along this frontier have changed considerably over time as environmental desiccation reduced the viability of agriculture and created greater competition between herders and farmers over relatively scarce pastures and fertile land. James Webb has argued that progressive desiccation of the Southern Sahara after the sixteenth century allowed Arabo-Berber pastoralists to attain an increasingly dominant position vis-à-vis 'Black' African agricultural peoples in areas along the southward moving 
ecological frontier of the desert. Increasing aridity gave pastoral groups a number of tactical advantages in competition for control over resources with sedentary communities, whose inhabitants were forced to either migrate further to the south, or to enter into subordinate relationships with pastoral overlords. The desert edge region that had once been controlled by large medieval states based in the lands to the south of the desert such as Ancient Ghana, Mali and Songhay disappeared and were replaced by much more localised political formations in which power often lay in the hands of Arabic- or Berber-speaking groups based either along the desert edge or in the southern confines of the desert itself. As these Southern Saharan groups came to dominate the desert edge, and the sedentary 'Black' African peoples who made up the majority of the local population, new ideologies of social organisation and racial difference were developed as corollaries to the changing political circumstances. With their increased power vis-à-vis agriculturalists, Arabic- and Berber-speaking pastoralists began to use racial identity as a more explicitly ideological justification of their position of domination over sedentary communities. ${ }^{23}$

Webb's work provides a convincing account of the social, economic and ecological factors that led to the increasing importance of racial ideas in local identities, but he does not explore the cultural and ideological tools that were used in constructing racial identities. Uncovering the intellectual history of these shifts is quite difficult for a number of reasons. Foremost among them is the fact that our access to the past is limited by extant written sources. We do possess some evidence but it has to be gleaned, for the most part, from texts devoted to subjects other than 'race.' A larger problem is that ideas about racial difference were embedded in a wider set of ideas about authority, social order, and religion. As such, we rarely encounter explicit statements about the meaning of racial difference. The arguments that we are able to make on the basis of this evidence are therefore subject to a number of caveats. The first is that by seeking to uncover and explain the historical development of racialised thinking in the Southern Sahara and Sahel, we are not arguing that this was the only, or even the most important, aspect of local identities in this area in the pre-colonial period. 'Race' became an important ideological component ordering relations between Arabic- and Berber-speaking groups on the one hand, and subSaharan Africans on the other. It developed out of changing relations of power between the different cultural groups along the desert edge. In the pre-colonial period, 'race' functioned primarily as a legitimisation of domination and enslavement of people defined as 'Black.' It is also important to underline that the ideas about racial difference that emerged along the desert edge were overwhelmingly cultural. Many people, such as the cosmopolitan communities of merchants and Islamic scholars in towns such as Timbuktu, remained largely outside the world of racial labels. These communities, often described by the name 'Takrūrı’’24 in local writings, played an important role in exchange and mediation across the borderland of the desert edge because of their ability to operate in a variety of cultural (and 'racial') contexts.

How then did notions of racial difference become important components of the political and cultural vernaculars of the people of the desert edge? The argument that we make here is that this process involved two fundamental intellectual 
moves. First, ideas about 'White' Arab Islamic culture that originated in the Islamic Middle East and North Africa were made part of Southern Saharan cultural identity by a reconfiguration of local genealogies connecting local Arabic- and Berber-speaking groups with important Arab Islamic historical figures in North Africa and the Arabian Peninsula. Second, local Arabo-Berber intellectuals rewrote the history of relations between their ancestors and 'Black' Africans in a way that made them the bearers of Islamic orthodoxy and the holders of religious authority in the Sahelian region. As such, the introduction of Islam into the region was attributed to these Saharan groups, and as such, contemporary authority in matters Islamic rested with them. The timing of these shifts is difficult to pinpoint, above all because they were part of much longer-term processes of cultural change in the Southern Sahara. The work of H.T. Norris and Abdel Wedoud ould Cheikh, among others, has made clear how scholars in the Southern Sahara reworked lineages using names taken directly from classical Arabic literature as part of a process of Arabisation. ${ }^{25}$ While this was a complex process that was on-going over many centuries, it seemed to attain a special importance with the ascendance of nomadic power in general, and of particular nomadic groups, during the seventeenth century and afterwards. As such, it corresponds roughly with Webb's periodisation of ecological change. According to many local historical traditions, the seventeenth century marks a watershed in the history of the Southern Sahara. It was at this time that the foundations were laid for the social and cultural structures of the region that we are familiar with today, especially in relations between so-called 'clerical' and 'warrior' groups so typical of Saharan society, and so prominent in the ethnographic literature on the region. It is also the moment when a number of in-migrations of subsequently dominant groups are deemed to have occurred according to local traditions. The so-called War of Shur Bubba in southwestern Mauritania is the best-known example, although there are many others all along the southern Sahara from the Atlantic Ocean to the region around Lake Chad. ${ }^{26}$ As an idealised representation of society, these foundation stories served to justify the social hierarchy found in the Southern Sahara. When examined from the point of view of the relationship that they establish between elite Southern Saharan communities and those defined as 'Blacks,' these stories also tell us something about local constructions of 'race. ${ }^{27}$

The significance of the idea of 'race' in the Southern Sahara is really an outgrowth of the increasing importance attributed to ideas about lineage connecting people living in this remote region with noble figures from Arab-Islamic history. The widespread reconfiguration of genealogies by Southern Saharan intellectuals to construct and reconstruct identities based on noble lineages was also a way of asserting a racial identity as 'White.' The models were metropolitan to a large extent (patrilineal, Arab, 'White'), but in both function and practice they often acted to invert earlier Arab ideas about 'race' inherited from pre-Islamic times that connected 'race' to environment and/or the story of the sons of Ham. Many early Arab writers assigned Hamitic origins to the inhabitants of the Southern Sahara (as well as to the Berbers of North Africa more generally). ${ }^{28}$ One of the consequences of the larger process of Arabisation that occurred in the Southern Sahara was a repudiation of this idea, at least as a basis for Southern Saharan identity, and a claim that Arab-ness rendered 
Southern Saharans genuinely Semitic. Once claims to Arab-ness were established, Southern Saharans could then play on another trope connected to ideas of 'race' from the early Islamic centuries: viz. that of the superiority of 'true' Arabs vis-à-vis nonArab Muslims clients $(m u w \bar{a} \vec{\imath})$ in matters of social privilege and in Islam. The Arab traveller and geographer Ibn Hawqal (d. 988) could write in the tenth century that 'Whites' who lived in the hot climate of Africa for seven generations became black and that the inhabitants of the Southern Sahara were the sons of Ham through their mothers. ${ }^{29}$ When ideas about 'race' were developed in the southern Sahara, local intellectuals insisted that a patrilineal relationship to an Arab ancestor, regardless of current skin colour, rendered them 'White.'

It is possible that racial discourses have a much longer history in the Southern Sahara than we know. Hints of an early significance for 'race' can be found in the Almoravid constructions of their Saharan past in ways that project an idea of perpetual hatred and domination over the 'Blacks' to the south of the desert, and perhaps also in the very old and widespread myth of Yemeni Arab (Himyarite) origins held by so many Saharan and Sahelian peoples. ${ }^{30}$ Yet in all likelihood, Almoravid discourse is part of a post facto ideology worked out in North Africa after attaining power, rather than a product of the contemporary intellectual environment in the Southern Sahara itself. Likewise, the Himyarite myths appear connected to an entirely different logic that is pre-Islamic. In any case, our access to these earlier notions of Arab ancestry is limited by the existence and/or availability of historical sources. Because written sources from the Southern Sahara itself are quite scarce before the seventeenth century, the likelihood of being able to push back much beyond this time seems remote. From the seventeenth century, we are on much more solid ground. We will use the seventeenth century as a threshold in our analysis of the development of racial discourses in the Southern Sahara. We first consider the intellectual foundations of ideas about 'race' by examining the most significant texts about the subject that circulated in the region before the seventeenth century. Then, we analyse the ways in which these ideas came to be associated with constructions of lineage, and with Islamic authority, beginning in the seventeenth century.

\section{Intellectual Foundations of 'Race'}

The larger history of ideas about 'race' in the Islamic Middle East is beyond the scope of this paper. What we hope to do in what follows is outline some of the most influential ideas concerning this subject that would have circulated amongst intellectuals in the Southern Sahara and Sahel. It is important to point out at the outset that although most metropolitan writers in Arabic held generally negative attitudes about 'Blacks' in particular, and towards most non-Arabs more generally, many also singled out individuals or groups who were exceptions to their larger derogatory evaluations. It was widely reported that the Prophet Muhammad had said to his followers: 'Look after the Blacks, for among them are three of the lords of Paradise, Luqmān the Sage, Najāshī and Bilāl the muezzin. ${ }^{, 31}$ The attribution of such a statement to the Prophet suggests a counter discourse on 'race' that was always available to Muslim writers from the very beginnings of Islam. Indeed, according to the Qur'ān, 
piety overrides any racial or ethnic quality. ${ }^{32}$ In the more detailed geographical and traveller writings, piety and adherence to Islam by 'Blacks' or other non-Arabs often renders them exceptions to the larger negative attitudes of the writers. In the hands of some writers, racial difference appears to hold little or no importance to understanding faraway peoples. ${ }^{33}$ There were also, as we shall see, writers who refuted some of the more general derogatory view of 'Blacks.'

Arab writers inherited two principle ideas about 'race' from pre-Islamic Mediterranean sources: an environmental theory about human difference and the biblical stories about Noah's sons Shem, Japheth and Ham. The intellectual debt that Arab writers had to earlier thinkers was often quite explicit. Al-Mas̀ ūdī (d. 956) for example, writing in the tenth century, quoted the second century Greek physician Galen on the inferior physical qualities of 'Blacks,' saying that 'merriment dominates the black man because of his defective brain, whence also the weakness of his intelligence. ${ }^{34}$ In general, Arab writers reproduced the classical Mediterraneancentred theory of world geography that divided the world into seven distinct regions, or climes, of which the medial fourth zone that coincided with the Mediterranean region was thought to be temperate and ideal for the development of human beings and civilisation. The extreme cold in northern regions and extreme heat in southern regions was thought to be responsible for the deficiencies of Europeans and Africans respectively. According to the fourteenth-century Syrian geographer al-Dimashqī (d. 1327), drawing extensively on earlier writers,

The equatorial region is inhabited by communities of Blacks who are to be numbered among the savages and beasts. Their complexions and hair are burnt and they are physically and morally deviant. Their brains almost boil from the sun's excessive heat ... The human being who dwells there is a crude fellow, with a very black complexion, and burnt hair, unruly, with stinking sweat, and an abnormal constitution, most closely resembling in his moral qualities a savage, or animals. ${ }^{35}$

Many other examples of such attitudes towards 'Black' Africans from medieval Arabic literature and geography could be marshalled. However, this environmental theory also was applied to other people who lived in climates similar to that of Africa and therefore, the inhabitants of South India and Indonesia found themselves identified alongside Black Africans in much of this literature. Over time, more information was gathered on sub-Saharan Africa and as a consequence, writers such as al-Bakrī (d. 1094), al-Idrīsī (d. 1154), Ibn Battuta (d. 1355), and most importantly Ibn Khaldūn (d. 1406) were able to add considerable detail to Arab knowledge about the bilād al-sūdān (the 'land of the Blacks'). As more was learned about the continent, writers began to use different terms to describe 'Black' Africans from various regions. The four main regional groupings that developed were the Zanj for people from the East African coast, the Habasha for Ethiopians, the Nūba for Nilotic groups, and the Sūdān for those in the Sahel west of the Nile Basin. The term 'Blacks' (sūdān) remained the generic label applied to sub-Saharan Africans, although it was also used in some cases to include non-Africans of dark complexion. ${ }^{36}$ 
An alternative theory explaining racial difference was that drawn from the biblical story of Noah's curse on his son Ham. The story of Ham is, in very obvious ways, a post facto popular religious justification for the widespread enslavement of 'Black' Africans, and it seems to have attained considerable popular acceptance. However, the story is not found in the Qur'ān, and many later writers did not accept it, in large part because it appeared to contradict the climatic theory of racial difference. According to a hadith, the Prophet Muhammad is reported to have said that the Arabs are the descendants of Shem, the Europeans the descendants of Japheth, and the descendants of Ham include not only the 'Black' Africans but also the Coptic Egyptians and Berbers. ${ }^{37}$ An early Arab account of this story comes from Ibn Qutayba (d. 889),

Wahb b. Munabbih said that Ham b. Nūh was a White man having a beautiful face and form. But Allah changed his colour and the colour of his descendants because of his father's curse. Ham went off, followed by his children. They settled on the shore of the sea, and Allah increased them. They are the Sūdān. Their food was fish, which used to stick to their teeth. So they sharpened their teeth until they became like needles. ${ }^{38}$ Some of Ham's descendants settled in the west. Ham begot Kūsh b. Ham, Kañān b. Ham and Fūt b. Ham. Fūt travelled and settled in the land of Hind and Sind, and the people there are his descendants. The descendants of Kūsh and Kañ ān are the races of the Sūdān: the Nūba, the Zanj, the Qazan [?], the Zaghāwa, the Habasha, the Qibt [Copts] and the Barbar [Berbers]. ${ }^{39}$

There are other versions of the story of Ham in Arabic literature that could be cited which trace the origins of 'Black' Africans and the Berbers in slightly different ways, but the important point is that the two peoples were considered by many to be, at the very least, genealogical cousins by those who invoked the Hamitic theory.

In an important sense, these genealogical myths are foundational to the subsequent development of ideas about 'race' and ethnicity in the Maghrib and the Sahara. From a very early date, Berber scholars attempted to refute the idea that they were descendants of Ham. A number of alternatives were proposed, including the idea that the Berbers were of Canaanite origin and descended from the giant Goliath, or that they were the descendants of pre-Islamic Yemeni (Himyarite) colonists in North Africa. ${ }^{40}$ Confronted with subjugation by an ethnically conscious Arab-Islamic conquest of the Maghrib, many Berbers found themselves in the subordinate position of clients $(m u w \bar{a} l \vec{\imath})$ in the hegemonic Muslim community. The desire to adopt Arab culture, to convert to Islam, and to be attached to Arab tribal affiliations must have been great. The growing familiarity of Muslim Berber scholars with Arabic literature, and in particular with the mythical heroic sagas of Arabia, allowed for reworkings of indigenous cultural material that aligned the Berbers with more prestigious ancestors. Of particular importance for these scholars was the discovery of a body of literature that originated in Yemen about the heroic exploits of the Yemeni Tubba kings in the pre-Islamic era, and their adventures in the lands west of Arabia. It was to these stories that Berbers attached themselves, making themselves Yemeni (Himyarite), and 
thereby Arab, in the process. ${ }^{41}$ These claims were far from universally accepted; the eleventh-century Andalusian writer Ibn Hazm, for example, denied them out of hand,

People have said that they are the remnants of the offspring of Ham ibn Nūh. Groups of them have claimed a Yemenite origin from Himyar, and some of them from Barr ibn Qays 'Aylān. This is false. There is no doubt at all. The genealogists have known of no son called Barr in the lineage of Qays `Aylān, nor had Himyar any access to the land of the Berbers save in the lies of the Yemenite historians. $^{42}$

Whatever historical veracity these claims may have, they were widely believed and have played an important role in establishing Berber claims to more honourable Semitic origins.

It is difficult to pinpoint with any precision the chronology of the absorption of these ideas by the people living in the Sahara Desert. Norris has argued that the mythology developed by Saharan people about past heroic Himyarite ancestors and their adventures incorporates aspects of the romance of Alexander the Great. ${ }^{43}$ It may be that the advent of Islam and the Arab conquest only precipitated a configuration of new names and exploits into a much older tradition. But is seems more likely that these older ideas came to the Berbers through the Arab writers who incorporated them into their works. One thing clearly does change with the Arabic literary models: the shift to much more strictly patrilineal models of descent. The Berbers traditionally traced their genealogies in matrilineal ways but in the hands of Arab or Arabised writers, this tended to disappear, or at least be complimented by patrilineal lineages connected to Arab ancestors. ${ }^{44}$ In the Southern Sahara, before the process of Arabisation began, perhaps in the fourteenth century, the impact of these changes further north was less important. As we have seen, when Ibn Battuta visited Walata in the fourteenth century, he remarked disapprovingly of the social freedom of Berber-speaking women, indicating perhaps that older Berber matrilineal structures were still in force. ${ }^{45}$ Even the Lamtūna Berbers, who were the first Saharans to enter onto the stage of world history with the Almoravid conquest of Morocco and Spain in the eleventh century, constructed a heroic past in the Sahara with a system of patrilineal descent only after they had established themselves in North Africa. That this past needed to be invented once in North Africa is understandable enough, but back in the Sahara, Berber speakers continued to follow older ways of understanding themselves and their past for many centuries to come. ${ }^{46}$

The two writers who had probably the greatest influence on later Southern Saharan ideas about 'race' were Ibn Khaldūn (d. 1406) and 'Abd al-Rahmān al-Suyūtī (d. 1505). Ibn Khaldūn was influential in a number of ways. ${ }^{47}$ His History of the Berbers (Kitāb al-'Ibar) was probably the most widely read text on North African history, and it provided later Southern Saharan writers with much of the historical and genealogical material they would need to construct 'improved' lineages for themselves. ${ }^{48}$ Ibn Khaldūn is somewhat inconsistent on the issue of 'race,' but insofar as he has a larger argument to make about the issue, he suggests that adherence to Islam 
redeems all other differences. In the Muqaddima, Ibn Khaldūn argues against the notion that blackness is related to descent from Ham:

Some genealogists who had no knowledge of the true nature of beings imagined that the Blacks are the descendants of Ham, the son of Noah, and that they were characterized by black colour as a result of a curse put upon him by his father, which manifested itself in Ham's colour and the slavery that God inflicted upon his descendants ... The curse of Noah upon his son is there in the Torah. No reference is made there to blackness. His curse was simply that Ham's descendants should be the slaves of his brothers' descendants. To attribute the blackness of Negroes to Ham, shows disregard for the nature of heat and cold and the influence they exert upon the air and upon the creatures that come into being in it. ${ }^{49}$

For Ibn Khaldūn, the explanation of racial difference lies in the Mediterraneancentred theory of climes:

As for the climes which are remote from the temperate regions, such as the First and the Second, and the Sixth and the Seventh, their inhabitants are very far from being temperate in all their features. For their buildings are of mud and reeds and their food is sorghum and herbs, and their clothes are of the leaves of trees with which they cover themselves, or skins. Most of them are devoid of clothing. The fruits and relishes of their country are of strange and abnormal form. Their transactions are not conducted with the two noble metals but with copper or iron or skins to which they assign a value for their dealings. Their manners, therefore, are close to those of dumb animals, so that it is related of many of the Sudan, the people of the First Clime, that they live in caves and in the jungle and eat herbs, and that they have the habits of beasts, not those of men, and eat each other. ${ }^{50}$

In this description, Ibn Khaldūn differs little from many writers who preceded him. Consistent with the theory of climes, Northern Europeans are marked out for equal approbation. But Ibn Khaldūn was also acquainted with the fact that there were people in sub-Saharan Africa who did not fit his description of barbarism. He had had close contacts with the Malian ruler Mansa Musa during his fourteenth-century pilgrimage, and he was well aware of past polities such as Ghana that were described in positive terms by writers such al-Bakrī. Since the first descriptions of Ethiopia, whose king had helped the early Muslims and who followed a revealed religion (Christianity), Muslim geographers had been faced with a similar challenge to the theory of climes. Ibn Khaldūn attempted to solve this problem by arguing that there were differences between the savages of the furthest reaches of the First Clime and the more advanced 'Blacks' who lived in closer proximity to the temperate zones in the Second Clime,

On account of their distance from temperate regions, the characteristics of their constitutions and manners are close to the characteristics of dumb animals and they are proportionately far from humanity. The features of their religion are the 
same; they are not acquainted with prophethood and do not submit to any revealed law except for such of them as are near to regions of temperateness, which is uncommon. ${ }^{51}$

But whereas writers such as al-Dimashqī had attributed the lack of revealed religion in the 'Black' regions to the very climatic factors that produced their barbarism, Ibn Khaldūn argued that this barbarism was redeemable through the adoption of a revealed religion, as had happened in a number of cases in Africa. As such, Ibn Khaldūn argued that the real touchstone of civilisation is not genealogy or climate, but religion. $^{52}$

Al-Suyūtī's influence on the Muslims of the Southern Sahara and Sahel was also very important, although for different reasons, and he even carried out a correspondence with scholars from the region from his home in Cairo. ${ }^{53}$ Al-Suyūtî's significance as an authority in the Islamic sciences is widely acknowledged in many Southern Saharan and Sahelian sources, and his views represented a flexible and liberal concession to local customs that stands in juxtaposition to the more legalistic and intolerant approach of the other major intellectual influence on West African Islam, Muhammad b. 'Abd al-Karīm al-Maghīlī (d. 1504), from Tlemcen. ${ }^{54}$ The more liberal perspective of al-Suyūtī manifested itself in a treatise he wrote in defence of 'Black' people called 'Raising the status of the Ethiopians' (Raf'sha'n $a l-h u b s h \bar{a} n$ ) and in an abridged version of this work entitled 'The Flowers of the throne concerning information about the Ethiopians' (Azhār al- 'urūsh fi akhbār $a l-h u b \bar{u}$ sh). ${ }^{55}$ The principle contribution of these works on the issue of 'race' was their attempt to demonstrate some of the virtues of 'Blacks.' Al-Suyūtī based much of his text on a similar book written by Ibn al-Jawzī (d. ca. 1200) entitled 'The Illumination of the darkness on the merits of the Blacks and the Ethiopians' (Tanwīr al-ghabash fì fadl al-sūdān wa- 'l-habash). ${ }^{56}$ In this work, Ibn al-Jawzī praises the 'Blacks' for their physical strength, bravery, generosity, good manners, harmlessness, cheerfulness, sweetness of breath, easiness of expression and fluency. ${ }^{57}$ Al-Suyūtī's Raf repeats much of Ibn al-Jawzî̀'s text and explains the origins of the 'Blacks' by laying out a series of hadiths that demonstrate their genealogy through Ham, although denying that their colour is the result of a curse by Noah. ${ }^{58}$ There are a number of works of a similar nature that purport to defend the 'Blacks' against their detractors. Al-Suyūtî's text is not especially original or outstanding in the context of this larger literature, but because of his reputation, the text was widely read and certainly influential. ${ }^{59}$

The importance of Ibn Khaldūn and al-Suyūtī to the development of racial thinking in the Southern Sahara is evident in a remarkable text written at the beginning of the seventeenth century by the celebrated Timbuktu jurist Ahmad Bābā (d. 1627) on the qualities of 'Black' people in the context of slavery. Ahmad Baba had been taken into forcible exile in Morocco after the successful Moroccan invasion of the Niger Bend beginning in $1591 .^{60}$ In Morocco, he found himself confronted with a much more racialised discourse - equating black-ness with slavery - than he was evidently accustomed to in Timbuktu, and this moved him to write a rebuttal of what he considered to be the false ideas of North Africans about 'Black' people in sub-Saharan 
Africa. A debate had apparently arisen in sixteenth-century North Africa about whether all 'Black' Africans were by definition non-Muslims, and therefore, whether they had permanent slave status regardless of later conversions or professions of Islam. The issue was provoked by the concerns of pious Muslims over whether it was legitimate to buy slaves imported from Africa who claimed to be Muslims. ${ }^{61}$ In response to a series of questions sent to him, Ahmad Baba, who was of Sanhāja Berber origin, ${ }^{62}$ refuted the popular North African idea that equated black-ness with slavery by what amounted to a rejection of North African ideas about 'race.' For Ahmad Baba, racial difference was of no importance to the issue of slavery; enslavement was only justified by non-belief in Islam, and this applied to all people, 'Black' and 'White':

[Y]ou know that the cause of enslavement is unbelief, and that the unbelievers of the Sūdān are like any other unbelievers in this regard - Jews, Christians, Persians, Berbers or others whose persistence in unbelief rather than Islam has been established ... This is proof that there is no difference between any unbelievers in this regard. Whoever is enslaved in a state of unbelief may rightly be owned, whoever he is, as opposed to those of all groups who converted to Islam of their own free will, such as the people of Bornu, Kano, Songhay, Katsina, Gobir and Mali and some of [the people of] Zakzak. They are free Muslims who may not be enslaved under any circumstances. $^{63}$

The argument that adherence to Islam trumps 'race' as a factor in enslavement according to Islamic law is very well established. The issue that concerned Ahmad Baba's questioners was whether or not there were legitimate Muslims amongst the 'Blacks' in sub-Saharan Africa, and if so, whether they had been converted to Islam by force, which would render them permanently enslaveable according to some authorities on Islamic law. To counter these ideas, Ahmad Baba relied on historical arguments about the spread of Islam in Africa, and the historical strength of certain Muslim states in Africa such as Ghana, Mali, and Songhay. To support his case, he quoted some of the most prominent Arab historians such al-Bakrī, al-Idrīsī, and Ibn Khaldūn. ${ }^{64}$ Ahmad Baba did not deny that there were unbelievers in Africa who could rightfully be enslaved; rather, he sought to demonstrate that some Africans had adopted Islam voluntarily and that there had long been Muslim states in Africa that raided other Africans who were non-Muslims. The dynamic of Islam in Africa was therefore an internal one, and Ahmad Baba listed those African states and peoples that were Muslim.

On the question of 'race' itself, Ahmad Baba discusses the Hamitic origins of the 'Blacks' as it was laid out in al-Suyūtī and Ibn al-Jawzī, both of whom he quotes. He seems non-committal about the question of the Hamitic origins of the 'Blacks' but he does reject the story of Noah's curse of Ham, supporting Ibn al-Jawzì's position that the story is incorrect, although he later suggests that perhaps the curse on Ham was effective on most of Ham's descendants, but not all of them. ${ }^{65}$ He quotes a hadith from the Prophet Muhammad cited by al-Suyūtī in the Raf' as the authoritative reason for racial difference: 'Adam was created from a handful [of earth] which 
[God] took from all parts of the world. Hence his offspring turned out according to the earth [they were made from]; some came out red, others white, others black, some were easy going, others downcast, some were evil and others good. ${ }^{66}$ Ahmad Baba then cites Ibn Khaldūn's environmental theory of racial difference. None of this seems to be especially important to Ahmad Baba because his position is, following Ibn Khaldūn, that the only important difference between human beings is religious. Because Islam is open to all people, and has adherents amongst all peoples, racial difference should play no role in distinguishing between the virtues of various people.

In defending 'Black' Muslims against popular attitudes in North Africa, Ahmad Baba sometimes reveals how he shared certain contemporary Arabo-Berber notions of the inferiority of 'Black' Africans. For example, he appears to embrace certain stereotypes about 'Black' Africans in general, remarking at one point on their 'objectionable characteristics and uncouthness, and their servile nature. ${ }^{67}$ It is however interesting that the first explicit discussion of 'race' by a Southern Saharan writer was provoked by an exposure to North Africa. Ahmad Baba's essential argument is that the North Africans just do not understand West Africa, and hence, they make serious mistakes regarding who can and cannot be legitimately enslaved. For someone such as Ahmad Baba, the abiding divide between people in West Africa is not their 'race,' but their qualities as free Muslims or non-believers. This argument would remain influential in the Southern Sahara and Sahel right down to the nineteenth century, when another writer from Timbuktu wrote a very similar work on the relationship between 'race' and slavery as he encountered it in North Africa. ${ }^{68}$ The rejection of a link between 'race' and Islam foreshadowed an important objection to the changes that would occur in Southern Saharan thinking about 'race' after the seventeenth century.

\section{Constructions of Authority, Constructions of 'Race'}

Ahmad Baba lived in a period of great change in the Southern Sahara and Sahel. The Moroccan invasion of the Niger Bend and the destruction of the Songhay Empire beginning in 1591 marked the start of a wider shift in political relations along the desert edge. Whereas Songhay authority had extended well into the Sahara as far as Taghaza and Agades at the height of its power, forcing many Berber-speaking nomadic groups into tributary relationships with the central state, by the seventeenth century, the loci of power had begun to shift towards the Saharan pastoralists who were increasingly able to impose themselves on sedentary populations. ${ }^{69}$ Similar developments occurred in other areas of the Sahel such as the Senegal Valley where pressures and interventions from 'Arab' groups to the north in Mauritania undermined existing Fulbe political structures. ${ }^{70}$ But if there was a shift at this time in the relative balance of power between communities based in the Southern Sahara and those located further to the south, there were also significant upheavals in the Southern Sahara itself that resulted in realignments of political power and status. These developments, which appear to have reached a climax in the second half of the seventeenth century, played an important role in subsequent ideological 
constructions of social relations within the Southern Sahara and in defining a set of idealised relations with people defined as 'Blacks.'

All across the Southern Sahara, local traditions speak of important events that established the dominance of particular groups. In the south-western Mauritanian region of the Gebla, a conflict known by the name of Shur Bubba in the 1670s is said to have marked the definitive conquest of Berber-speaking lineages by Hassānī Arab groups. As a result of this defeat, the conquered lineages foreswore military activities and assumed the subordinate social role as Islamic religious specialists. As such, the hierarchical distinction between 'warrior' (hassān) and 'clerical' (zawāya) lineages was formalised. In other parts of the Southern Sahara, similar stories tell of the emergence of subsequently dominant groups among the Tuareg in approximately the same period. In the Aïr Massif, the arrival of the Kel Ewey and their displacement of the previously established Kel Gress and Kel Ferwan occurred in the second half of the seventeenth century. Likewise, the Iwillimmeden confederacy, the Kel Antessar and the Kunta appear to have achieved their political importance at about this time. ${ }^{71}$ Scholars have debated the degree of importance to attribute to these occurrences in the establishment of Southern Saharan social structures and cultural identity. ${ }^{72}$ Certainly, the local representations of these events simplify more complex processes of migration and political change that must have occurred over longer periods of time. Also, the dichotomy established between so-called 'warrior' and 'clerical' lineages and their respective social roles does not fully reflect actual social practice or changes in status over time. ${ }^{73}$

Nobody suggests that the seventeenth century marks the beginning of Southern Saharan history, or that the social and cultural formations that appear to have been formalised at this time were not continuous with what was already there. From at least the time of the Almoravids, to the Imagsharen hegemony in the Niger Bend in the fifteenth century, the Kel es-Suq in the Adrar Iforas, and the Tuareg groups in the Aïr Massif, we have recognisable antecedents to more recent social configurations. The process of social and cultural change in the Southern Sahara was unquestionably a gradual one, but it is equally clear that a complex process of what we may call 'Arabisation' was occurring. This process was subject to wide variation. In the western regions of the Southern Sahara, Arabic was increasingly adopted as a language of daily social intercourse by formerly Berber-speaking populations. This did not occur to nearly the same extent in eastern areas where Tuareg groups predominated. However, the Arab influence should not be judged solely by the criteria of adoption of the Arabic language. The importance that the 'social charters' of the seventeenth century assign to specialisation in Islamic religious knowledge, and to the so-called 'clerical' lineages (zawāya, inesleman in Tuareg society), suggest that Islam itself was becoming a more important component in Southern Saharan identities. $^{74}$ By entering ever more fully into the world of Arab Islamic culture, and by constructing and elaborating on genealogical connections to important Arab Islamic ancestors, the elite stratum in Southern Sahara society increasingly defined itself as part of one world, and distinct from another. In the fourteenth century, the Arab geographer al-'Umarī reported that in the land of the 'Blacks' there are three independent 'white' Muslim kings who are Berbers. He was referring to the sultan 
of Aïr, the sultan of Tādmakka in the Adrar Iforas, and a third sultan whose identity is unclear. ${ }^{75}$ By the end of the seventeenth century, local writers in these areas located the 'land of the Blacks' significantly further to the south. The Southern Sahara, or, simply 'the desert' (al-sahrā') as it is commonly referred to in local sources, had become the field of action for non-'Blacks.' Whereas Ahmad Baba sought to delink 'race' and adherence to Islam when addressing a North African (or at least Saharan) audience, later writers in the Southern Sahara would do their utmost to ensure that religious authority was entangled with lineage. White-ness is therefore not really about the skin colour or physical characteristics of those who identified themselves as 'White,' although it did sometimes manifest itself in this way in descriptions of founding figures ${ }^{76}$ rather, it lies in the accepted genealogical connection to important figures in the historical and religious pantheon of Arab Islam. Blackness by contrast, is defined by the lack of such connections. In many Arabic documents written in the Southern Sahara, the label of 'Blacks' (sūdān) appears in opposition to the word for 'Muslims' (muslimūn). ${ }^{77}$ To be 'Black' is to be a son of Ham; to be 'White' is to be a bearer of the 'true' Islam.

The Southern Saharan written literature on local history and genealogy is characterised by extremely obvious borrowings from important works on these same themes produced in the wider metropolitan Arab world. Certainly, much of the reason for this lies in the form of such literature, which placed a high premium on acknowledged and accurate quotations from accepted authorities. Writers such as Ibn Khaldūn were often quoted directly by Southern Saharan writers on issues such as the early Berber populations that lived in the area in medieval times. Likewise, there are locally written manuscripts that detail the Hamitic origins of the 'Blacks' and Berbers in much the same way as has been done above. ${ }^{78}$ The important function of this borrowing, whether acknowledged or not, is that it allowed Southern Saharan intellectuals to insert their more local historical or genealogical material into a larger, existing structure or narrative that was part of the larger Arab Muslim world. Although almost impossible to prove definitively, it seems likely that the fairly widespread production of written Arabic texts in the Southern Sahara was itself the product of the larger process we have been considering, whereby local intellectuals anyhow, increasingly identified with Arab Muslim culture. In any case, almost all of the extant written material produced by Southern Saharan intellectuals was produced after the seventeenth century. Where earlier material has been discovered, the overlay of external motifs and sources is less significant. $^{79}$

The genealogical claims made by virtually every significant 'noble' group in the Southern Sahara, whether Arabic or Berber speaking, invoke an Arab Muslim origin. The relative strengths of different genealogical claims vary significantly in ways that suggest historical competition over power and status among different groups that has continued down to the present day in some cases. ${ }^{80}$ Broadly speaking, most Arabophone 'warrior' (hassān) lineages trace their descent to Ja far b. Abī Tâlib (brother of 'Alī and cousin of the prophet Muhammad) ${ }^{81}$ through a branch of the Banū Hilāl, one of the principle Arab tribes that migrated into North Africa in the eleventh century. In particular, these groups claim a common ancestor in Hassān, who 
was a member of a sub-group of the Banū Hilāl called the Banū Mà qil, members of which had penetrated into northern Mauritania by the fourteenth century. ${ }^{82}$ Whatever may be the complex history of the migration of Arab groups into the Sahara, and their ability to attract and assimilate clients, local historical traditions represent the emergence of Arab hassān hegemony as a result of invasions and decisive military victories. ${ }^{83}$ It is important to note that the model of hassānī descent was also taken up, at least in part, by some dominant Tuareg groups that assumed the same role as the 'warrior' lineages in Arabophone areas. The Iwillimmeden noble (imajaghen) lineages, for example, claim that their founding figure, Muhammad Wa-n-Ara was a hassānī Arab born in southern Mauritania in the middle of the sixteenth century. He later came to the Adrar Iforas and offered his military services to the chief of the Tuareg of Tādmakkat. As a reward for his services, he married the daughter of this chief. It is from this line that some Iwillimmeden claims to Arab origin arise. ${ }^{84}$

The genealogical claims made by many zawāya or inesleman groups are premised on a different kind of authority. Unlike their 'warrior' cousins, zawāya groups could not rely on the same narratives of conquest to establish their historical position. Instead, they generally establish links to a 'saintly' ancestor and thereby connect themselves to the 'unseen' power of religious knowledge. Because these groups are, at least in theory, specialised in the practice of the Islamic religious sciences, it is not surprising that they would structure their decent from renowned religious figures. But the authority that these groups claim is derived both from a mastery of the Islamic religious sciences and from a privileged position allowing special knowledge of God, what is called 'waläya' in Arabic, a term usually translated as 'saintliness' or 'nearness to God.' It is very common in the local histories of these groups to find references to the important awliya ' ( local ancestors from whom authority is at least partly derived. One of the bestknown examples of this sort of genealogy comes from the Tashumsha, the zawaya group whose defeat in the War of Shur Bubba confirmed their zawaya status. The Tashumsha attach themselves historically to Nāsir al-Dīn, the religious leader who launched this war and was ultimately killed by his hassānī Arab enemies. But the Tashumsha also claim descent from Abū Bakr, the companion of the Prophet Muhammad and the first caliph. ${ }^{85}$

Similarly, the people of Arawan in the Azawad trace their decent to a religious figure named Ahmad ag Adda (d. 1635) and several companions, who founded the desert town of Arawan in the late sixteenth century as a religious sanctuary. According to local traditions, Ahmad ag Adda, who was a member of the Kel es-Suq of the Adrar Iforas, came to the area where he would establish Arawan after his original home in the Adrar Iforas had been destroyed by Songhay rulers. Ahmad ag Adda and his companions 'became famous for jurisprudence and for their sanctity and faith. They enjoyed a status of inviolability (hurma) throughout all the land. People began to bestow alms upon them and to seek their baraka, from them and from their descendants until today. ${ }^{86}$ Among the pieces of evidence recounted in local histories demonstrating his status as a 'saint' (wal $\vec{l}$ ) is an episode in which he and a slave were imprisoned by the Moroccan conqueror of Songhay, Jawadir. Despite being placed in irons, Ahmad ad Adda was able to 'miraculously' free himself and 
his slave at the appointed moment for prayers. When asked to explain how he was able to accomplish this feat, he responded simply in a manner befitting a 'saint': 'With the permission of God. ${ }^{87}$ But if the people of Arawan, and those related to them such as the Kel Antessar, ${ }^{88}$ base their authority on their connection to Ahmad ag Adda and his descendants, they also claim a prestigious Sherifian genealogy through 'Uqba b. Nāfi' (d. 683), the Arab Muslim conqueror of North Africa, to 'Alī b. Abī Tālib. ${ }^{89}$

The importance of both a prestigious Arab Muslim genealogy and local ancestors recognised as 'saints' in constructions of authority among zawāya groups is perhaps best illustrated by the case of the Kunta, an important Arabophone zawāya lineage based in the Azawad in the eighteenth and nineteenth centuries, and perhaps the most prolific of any group in producing written materials. The Kunta gained prominence in the Azawad during the lifetime of Sīdī al-Mukhtār al-Kuntī (d. 1811) and his son, Sīdī Muhammad (d. 1826). Under the leadership of these two men, the lineage built an important commercial network connecting the Sahel with Saharan entrepôts such as Touat. ${ }^{90}$ However, the Kunta are better known for their role as Islamic scholars and 'saints,' attracting novices, or 'talāmīdh' from across Islamic West Africa. ${ }^{91}$

The Kunta claim a role of prominence in the Southern Sahara that goes back many centuries. Like the Kel es-Suq, the Kunta trace their descent from` Uqba b. Nāfi . They claim to have formed in Qayrawan (in Tunisia), where they say, wrongly, that 'Uqba is buried. ${ }^{92}$ Sīdī Muhammad describes the Kunta origins as follows,

The Kunta, according to the unanimous agreement of the principle historians, originated in Qayrawan; and there is found the tomb of their ancestor, the most ancient in Islam, 'Uqba al-Mustajāb, son of Nāfi', to whom God granted victory over the region of Ifriqiya as far as Ghana and Berki al-Ghamād, called in our time Bu Rigrig. ['Uqba] left his son al-'Aqib in Sira, ${ }^{93}$ today called Walata; and his grave is in the courtyard of the mosque that he built there. 'Uqba made other expeditions with those who returned with him, devastating the regions of Takrūr, and he took its cities and its villages, one after the other, until he reached the district of Bawwar, inhabited at that time by the Awrabiyūn. ${ }^{94}$ He besieged them for a month and then a mighty slaughter occurred between them in which many of his soldiers were martyred. ${ }^{95}$

According to Sīdī al-Mukhtār al-Kuntī in his Kitāb al-Minna, the Kunta maintained their genealogical purity from the time of 'Uqba until the time of Sīdī Ahmad al-Bakka'̄ Bū Dam' (d. 1515) by a practice of killing off all children except for one, who was chosen by the father as his successor,

Amongst their traditions that are reported to have passed down from father to son is that in the event that one of them became father of several children, he educated and trained them. When he felt his end approaching, he chose from amongst them the one who was noteworthy for his virtues and ability and was thus worthy to succeed him, endowed him and expressed the wish that God took the souls of others. ${ }^{96}$ 
This story is clearly a genealogical trick to project directly backwards to 'Uqba and avoid the necessity of filling in the lineages that would have been produced by different branches of the family. ${ }^{97}$ When Sīdī Ahmad al-Bakka'̄̄ Bū Dam'abolished this custom, the Kunta enter into the universe of the Southern Sahara at Walata, and produce their first local 'saint.' In one example, Sīdī Ahmad saved the village from wild lions by a miracle. Sīdī Ahmad also established a religious school in Walata and began to attract students. Apparently, he encouraged the education of women but insisted on the separation of the sexes and lectured to his female students from behind a curtain. He exhorted the women to observe hijāb (covering themselves for reasons of modesty), thereby emphasising his Arab identity in criticising what can only be interpreted as older Berber norms of free mixing of the sexes reported on so disapprovingly by Ibn Battuta. Sīdī Ahmad reputation for piety and miracles is said to have grown in the Southern Sahara, and when he died in 1515, he was buried on the bank of a seasonal stream near Walata. It was as caretaker of this tomb that Sīdī al-Mukhtār al-Kuntī began his career as a saint two hundred and fifty years later. ${ }^{98}$

The connection to 'Uqba b. Nāfi'made by the Kunta and others, including the Iwillimmeden, ${ }^{99}$ is interesting because it illustrates a larger pattern in Southern Saharan local histories about the structure of relations with people defined as 'Blacks.' Uqba b. Nāfi was the Arab Islamic conqueror of North Africa, and the founder of the new Muslim capital at Qayrawan in 670. According to the accounts of Arab historians, his campaigns against the Berbers took him all the way to the Sous in Morocco, where he reached the shore of the Atlantic Ocean. He was killed in 683 in an ambush laid by a combined force of Byzantines and Berbers. ${ }^{100}$ Although 'Uqba's campaigns were concentrated along the North African littoral, he did make one punitive excursion into the interior of the Fazzān, reaching the oasis of Kawār, from which he took a number of slaves. ${ }^{101}$ It seems likely that these slaves were Saharan Berbers rather than 'Black' Africans because the chronicles make no mention of their ethnic or racial identity. Furthermore, 'Black' African slaves did not appear in North African slave markets until the end of the seventh century. ${ }^{102}$ Nonetheless, in the Kunta account of 'Uqba's campaigns, the claim is made that the jihād reached all the way across the desert to the land of Takrūr. They say that 'Uqba and his forces penetrated deep into the land of the 'Blacks' and reached a place where no animal could survive the heat of the sun. ${ }^{103}$ The idea that 'Uqba waged jihād against the 'Blacks' is widely believed by many people in the Southern Sahara and Sahel and there is some basis in the eleventh- and twelfth-century texts of al-Bakrī and al-Idrīsī that might have led to such a construction. ${ }^{104} \mathrm{~A}$ second expedition under the command of a grandson of 'Uqba named Habīb b. Abī Ubayda to the Moroccan Sous and the land of the 'Blacks' is mentioned in Arab historical sources and also claimed by the Kunta. ${ }^{105}$

The historical likelihood of such military expeditions against the 'Blacks' in these early centuries is remote. However, by connecting themselves to historical characters such as 'Uqba who brought Islam to Africa, groups like the Kunta were able to make the argument that they too were the bearers of Islam. North African historians and 
chroniclers had used the story of 'Uqba to elaborate the beginnings of the relationship between Arab Muslims and the Berbers. In effect, the Kunta picked up on this tradition and extended it to include the 'Blacks' of the Sahel. As such, the Kunta were able to situate themselves as the first to bring Islam to West Africa and the first to wage jihād against local infidels.

The story of 'Uqba's conquests of the 'Blacks' is only one example of Kunta claims to have always been at the vanguard of Islam in the Southern Sahara and Sahel. They also wove themselves into other histories of past relations between important Arab Muslims and local 'Blacks.' In the Kitāb al-tarā'if wa-'l-talā'id, Sīdī Muhammad narrates a story about a meeting that took place in West Africa between Sīdī 'Umar al-Shaykh al-Kuntī (d. 1552/3) and Muhammad b. `Abd alKarīm al-Maghīlī, the highly influential fifteenth-century Muslim scholar from Tlemcen who spent time in West Africa. During this meeting, al-Maghīlī was highly impressed with the Kunta shaykh's vast knowledge of the Islamic sciences. The two became friends and the Kunta shaykh was trained by al-Maghīin in esoteric knowledge ( $i l m$ al-bätin). At some point, the two men headed on the pilgrimage to Mecca, and stopped along the way in Egypt where they met with al-Suyūtī. The Egyptian was impressed with al-Maghīlî's vast knowledge and accorded him pre-eminence in both his knowledge of the Islamic sciences and in sanctity. Later, al-Maghīlī and the Kunta shaykh returned home to West Africa and became involved in a wellknown historical relationship that connected al-Maghīlī with the Songhay rulers and with the town of Katsina. There was a disagreement between the Songhay ruler and al-Maghīlī over the death of one of al-Maghīlī's sons in Touat at the hands of the local population. The Songhay ruler refused to punish the entire town so al-Maghīlī left Gao [the Songhay capital] and went to Katsina. Such was the wrath of al-Maghīlī at the Songhay ruler's behaviour that he cursed the entire Songhay kingdom,

His city of Gao is a ruin-field; the state of Songhay is lost and has perished. We have transferred its structure to Katsina and the latter will be the capital [of Takrūr] until the command of Allah comes. Then Touat will be smitten and He will ruin that town and He will wipe out its people and it is now as good as ruined. ${ }^{106}$

When al-Maghīlī was about to die, he assembled the people who were there and told them that anyone who desires his baraka must seek it from the Kunta Shaykh, Sīdī 'Umar. ${ }^{107}$

This story is clearly fictional. There is no external evidence to corroborate any meeting between al-Suyūtī and al-Maghīlī, and the apparent failure of the Songhay ruler to act against the people of Touat after the death of al-Maghīlī's son is contradicted by other evidence that suggests all people from Touat in Songhay were arrested after news of this event reached Gao. Above all else, the dates do not match. ${ }^{108}$ However, like the story of 'Uqba, the connection to al-Maghīlī acts to legitimise Kunta claims to Islamic authority in West Africa. Having taken up the mantle of al-Maghīlī's baraka, the Kunta can claim their rightful role as masters in the tutelage of the 'Blacks' in matters of Islam. In effect, these stories act to structure an unequal 
relationship between the Kunta as the bearers of Islam, and the 'Blacks' who have always been, at best, the recipients of Islamic counsel, and at worst, non-Muslims who are the legitimate target of jihād and God's wrath.

\section{Conclusion}

The Kunta were not alone amongst zawāya groups in weaving themselves into narratives of power and domination over people defined as 'Blacks.' The main protagonists in the War of Shur Bubba, the Tashumsha, make explicit the connection between their founding 'saint,' Nāsir al-Dīn, and the jihād he waged against 'Blacks' defined as 'infidels' (kuffār) in the Senegal River Valley. ${ }^{109}$ Likewise, the founding figure of Arawan, Ahmad ag Adda, is given a role in the Moroccan invasion of Songhay. After being imprisoned by the Moroccans, it will be recalled that Ahmad ag Adda escaped from his chains. This so impressed the Moroccan expeditionary leader Jawadir that he bowed before the authority of this 'saint' and, according to this tradition, would only attack the (Songhay) 'Blacks' with Ahmad ag Adda's permission, which was granted. ${ }^{110}$ 'Race' is by no means the only, or even the most important, aspect of these constructions of authority. But ideas about racial difference are clearly a part of the intellectual tapestry of the Southern Sahara and Sahel after the seventeenth century. What has been presented here is an analysis of an important strand of the intellectual development centred in Southern Sahara zawāya communities whereby authority was constructed, and transferred, by means of lineal connections over time. As we have shown, these lines were simultaneously religious, ethnic and racial.

I would like to make a couple of points by way of a conclusion. There is a significant difference between ideas about colour and those of 'race.' The position that the Kunta sought to occupy in the Southern Sahara and Sahel required that they be at the head of a religious network that included people from across the area, including 'Blacks.' But the Kunta, like other Southern Saharan groups, also recognised colour differences in their own lineage. In the al-Risāla al-Ghallāwiyya, Sīdī Muhammad explains a split that had occurred within the ranks of the Kunta during the seventeenth century because of a war that broke out between the 'White' Awlād Mallūk and the 'Blacks' $(a l-k u h l) .{ }^{111}$ The term used to describe 'Black' members of the Kunta is $k u h l$, and not the term sūdān, which was reserved for the non-Arabo-Berber 'Blacks' of sub-Saharan Africa. It is the label sūdān that carried the set of assumptions connected to ideas of racial difference. At root, the ubiquity of this term highlights the process whereby ethnic differences between peoples who identified themselves with the desert of the Southern Sahara, and those populations indigenous to sub-Saharan Africa, were racialised. The idea of 'race' that appears in the pre-colonial literature of the Southern Saharan is therefore closely correlated with the idea of lineage. The absence of genealogical connections to Arab Muslim ancestors was what rendered one 'Black.' Since 'Blacks' (sūdān) did not have the lineal connection to important bearers of Islam in the Southern Sahara and Sahel, they were put in the position, ideologically, of permanent tutelage or clientage to groups like the Kunta. Like the early non-Arab Muslims of the first centuries of Islamic history in the Middle East, 
'Blacks' along the desert edge were assigned the position of clients (muwāl $\vec{\imath})$ in the constructions of authority made by scholarly Arab Muslim elites. Free 'Blacks' $(k u h l)$ who were ethnically Kunta did not find themselves defined in this way.

It is important to stress that these Southern Saharan constructions of racial difference examined here were neither unique in West Africa, not did they go uncontested. Nobles in many Sahelian societies such as the Fulbe and Songhay also considered themselves to be distinct from 'Blacks.' One might argue therefore, that there is a strong element of class at work in the development of ideas of racial difference. A single example will have to suffice. The elite stratum of the Songhay-speaking population in the Niger Bend known as the Arma, ${ }^{112}$ claimed descent from Moroccan soldiers who invaded the area in the late sixteenth century. These Arma had long insisted that they were not 'Blacks,' although others contested this view, especially during the colonial period. One critic of these Arma claims was Ahmad Bul'arāf al-Tiknī, who lived in Timbuktu and was himself of more recent Moroccan origin. In a work written in 1941-42, he conceded that the Arma population of Timbuktu was of 'White' origin. ${ }^{113}$ However, he argued that their status as 'Whites' had been greatly diminished by the fact that they have lost the knowledge of the their precise genealogies:

They do not know their origins for the most part, and no person from the Draa Valley, or the Atlas Mountains, or Fes is mentioned. The meaning of this is that the army of Mawlay [Ahmad al-Mansūr] took soldiers from every tribe, and when they entered the land of the Sūdān. . they got mixed up in this country... and they have all been transformed into Blacks except for some of them who have a reddish colour with thin arms and legs, which is proof of their Arabness; but they do not speak Arabic for the most part. ${ }^{114}$

Such arguments became more prolific during the period of European colonial occupation, and they found support in the policy of the French colonial regime that applied the label of 'Blacks' to the entire Songhay-speaking population, including the Arma. However, we can still see in the middle of the twentieth century how important known and accepted genealogies were to local ideas about 'race'.

\section{NOTES}

1. Presumably, the Ahaggar Tuareg.

2. The exception is in a description of the women of a Tuareg group called the Bardāma: 'Their women are the most perfect of women in beauty and the most comely in figure, in addition to being pure white and fat.' Ibn Battuta in Black Africa. Said Hamdan and Noel King (ed. and trans.) (London: Rex Collins 1975), p.56. The Arabic is 'ma'al-bayād al-nāsi'’ Ibn Battūta, Rihla ibn battūta (Cairo: al-Maktaba al-Tijāriya al-Kubrā 1967), p. 208.

3. Ibid., p. 28.

4. See for example, Bernard Lewis, Race and Color in Islam (New York: Harper \& Row 1971); idem, Race and Slavery in the Middle East. An Historical Enquiry (New York: Oxford University Press 1990); and G. Rotter, "Die Stellung des Negers in der islamisch-arabischen Gesellschaft bis zum XVI Jahrhundert" (Dissertation, University of Bonn 1967).

5. The use of the term 'race' to describe non-European constructions of human difference, especially prior to European colonial expansion, may raise some objections. I argue that using the term is appropriate when confronted with cultural ideologies of human difference that rely on ideas of 
innate somatic differentiation and when skin colour distinctions are constructed as the main markers of that difference. These conditions have been met in a wide variety of historical contexts outside of Europe, although there are no non-European cases that I am aware of in which the 'scientific' evolutionary models of 'race' that developed in nineteenth-century Europe and North America arose independently. In China and India, ideas about 'race' developed out of rather natural equations of civilisations with humanity, of skin colour with moral character, and of foreigners with barbarous monsters. See Peter Robb, 'Introduction: South Asia and the concept of race', in Robb (ed.) The Concept of Race in South Asia (Delhi: Oxford University Press 1995), p. 75 and passim; Frank Dikötter, The Discourse of Race in Modern China (Stanford: Stanford University Press 1992), pp. 1-30. These were essentially cultural constructions of 'race' very similar to the earliest European racial theories up though the eighteenth century by which 'race' was equated, variously, with lineage, tribe, ethnicity, caste, religion or even 'nation.' See for example, David Theo Goldberg, 'The semantics of race', Ethnic and Racial Studies 15(4), (1992), p. 545; Michael Banton, Racial Theories (Cambridge: Cambridge University Press 1987), pp. 1-27; E.J. Hobsbawm, Nations and Nationalism since 1780. Programme, myth, reality (Cambridge: Cambridge University Press 1992), p. 65; Pierre H. Boulle, 'François Bernier and the Origins of the Modern Concept of Race', in Sue Peabody and Tyler Stovall (eds.), The Color of Liberty: Histories of Race in France (Durham: Duke University Press 2003), p. 12; Roxann Wheeler, The Complexion of Race: Categories of Difference in Eighteenth-Century British Culture (Philadelphia: University of Pennsylvania Press 2000).

6. The people Mungo Park stayed with were the Awlād Mubārak, a hassānī Arab group that attained a position of dominance in the Hodh in the seventeenth century. The name 'Ludamar' that Park gave to this 'kingdom' was derived from the name Wuld 'Umar, the leader of the Awlād Mubārak in this area until 1762, and presumably, the name Park heard in reference to the princely lineage. H.T. Norris, The Arab Conquest of the Western Sahara. Studies of the historical events, religious beliefs and social customs which made the remotest Sahara a part of the Arab world (London: Longman 1986), p. 70.

7. Mungo Park, Travels in the Interior Districts of Africa, Kate Ferguson Marsters (ed.) (Durham: Duke University Press 2000), p. 140.

8. Ibid., p. 162.

9. Caillié uses the Songhay term 'Sourgou' for the Tuareg.

10. René Caillié, Journal d'un voyage à Temboctou et à Jenné, dans l'Afrique centrale (Paris: Editions Anthropos 1830), v.2, pp. 281-82.

11. Hienrich Barth, Travels and Discoveries in North and Central Africa (New York: F. Cass 1859), v.3, p. 439.

12. We do not possess a complete inventory of local manuscript material. Nonetheless, a project called the 'West African Arabic Manuscript Database' that includes information on approximately 21,000 manuscripts from across West Africa has been compiled at the University of Illinois. This database can be searched on line (http://www.arabic.uiuc.edu/). There are 81 titles in this database that include the word sūdān, and 7 titles that include the term bīdān. Some of the works with sūdān in the title are duplicate copies of the same work, but it does at least demonstrate just how common such terms were in local literature.

13. Urs Peter Ruf, 'Ending Slavery. Hierarchy, Dependency and Gender in Central Mauritania', (Dissertation, University of Bielefeld, 1998), p. 38; Catherine Taine-Cheikh, 'La Mauritanie en noir et blanc. Petit Promenade linguistique en Hassaniya', Revue du Monde Musulman et de la Méditerranée 54 (1989), pp. 90-105.

14. Baz Lecocq, “That Desert is Our Country": Tuareg Rebellions and Competing Nationalisms in Contemporary Mali (1946-1996)', (Dissertation, University of Amsterdam, 2002), p. 12.

15. Hallasy Sidibé, Mamadou Diallo and Coumbel Barry, 'Pulaaku et crise d'identité: le cas des Fulbe wodeebe (Peuls rouges) de la région lacustre de l'Issa-Ber au Mali' in Mirjam de Bruijn and Hans van Dijk (eds.) Peuls et Mandingues. Dialectique des constructions identitaires (Paris: Karthala 1997), pp. 226-28.

16. Jean-Pierre Olivier de Sardan, Concepts et conceptions songhay-zarma (Paris: Karthala 1982), pp. 144. When the American anthropologist Horace Miner carried out research in Timbuktu in 1940, he found that these terms were still in use: Miner, The Primitive City of Timbuctoo (Garden City, NY: Anchor Books 1965), pp. 54-62.

17. Ruf (note 13).

18. Gilles Boëtsch and Jean-Noël Ferrié, 'De la modernité paradoxale du point de vue de l'anthropologie physique sur les groupes serviles au Sahara', in Mariella Villasante-de Beauvais (ed.) Groupes Serviles au Sahara. Approche comparative à partir du cas des Arabophones de Mauritanie (Paris: CNRS 2000), pp. 269-75. 
19. For example, Hélène Claudot-Hawad, 'Captif Sauvage, Esclave enfant, Affranchi Cousin... La mobilité statutaire chez les Touaregs (Imajaghen)', in Villasante-de Beauvais (ed.) Groupes Serviles au Sahara (Paris: CNRS 2000), pp. 258-59.

20. It is important, I think, to acknowledge that somatic difference along the Sahel is a reality, and that this difference does play a role in the existence of notions of racial difference. Racial thinking though, moves beyond this perception of difference and both privileges certain types of human difference (often arbitrarily) and ascribes to it meanings which are objectively false. It is at this level at which 'race' becomes an ideology or discourse that it tends to lose its relationship to what we might posit as objectively true: i.e. that there are real differences between human beings. See Robb (note 5), pp. 65-68. There is no direct or even necessary relationship between racial thinking and objective human difference, as any serious study of 'race' along the Sahel demonstrates. On this issue in Sudan, see A. Idris, Sudan's civil war: Slavery, race and the formation of identities (Lewiston, 2001); J. Jok, War and slavery in Sudan (Philadelphia: University of Pennsylvania Press 2001).

21. Max Weber, From Max Weber: Essays in Sociology (New York: Oxford University Press 1958), p. 189.

22. Donald Horowitz, Ethnic Groups in Conflict (Berkeley: University of California Press 1985), pp. $22-23$.

23. James Webb, Desert Frontier: Ecological and Economic Change along the Western Sahel, 16001850 (Madison: University of Wisconsin Press 1995).

24. The term 'Takrūr' is usually considered to be a rather vague geographical reference, referring to the Sahelian and Saharan fringe in West Africa. See John Hunwick, Timbuktu and the Songhay Empire. Al-Sa 'di's Ta'rikh al-sudan down to 1613 and other Contemporary Documents (Leiden: Brill 1999), $53 \mathrm{ff}$. But when used to refer to people, the term was reserved for the cosmopolitan Muslim scholars who lived along this borderland, and not for all the regions inhabitants. See J. Spencer Trimingham, $A$ History of Islam in West Africa (London: Oxford University Press 1962), pp. 41-42; Umar al-Naqar, 'Takrur: The History of a Name', Journal of African History 10/3 (1969), pp. 365-74. On Tuareg usage of this term in this way, see Hélène Claudot-Hawad, 'Identité et altérité d'un point de vue touareg. Eléments pour un débat', in Claudot-Hawad, (ed.), Touaregs et autres Sahariens entre plusieurs mondes. Définitions et redéfinitions de soi et des autres (Aix-en-Provence: Les cahiers de l'IREMAM; 7-8, 1996), p. 14.

25. The most important works are Norris, The Arab Conquest of the Western Sahara; Abdel Wedoud ould Cheikh, 'Nomadisme, Islam et pouvoir politique dans la société maure pré-coloniale', (Dissertation, Paris V, 1985).

26. For a discussion of these foundation stories see C.C. Stewart, 'Southern Saharan Scholarship and the Bilad al-Sudan', Journal of African History 17 (1976), pp. 73-93; Norris, 'Znaga Islam during the seventeenth and eighteenth centuries', Bulletin of SOAS 32 (1969), pp. 496-536; idem, The Arab Conquest of the Western Sahara.

27. These are idealised representations of social hierarchy and as such, they fail to account for the actual historical dynamism and social mobility that occurred in the Southern Sahara since the seventeenth century. See Timothy Cleaveland, Becoming Walāta: A History of Saharan Social Formation and Transformation (Portsmouth: Heinemann 2002), pp. 3-36.

28. H.T. Norris, The Berber in Arabic Literature (Beirut: Libraitie du Liban 1982), p. 34.

29. Ibn Hawqal, Surat al-Ard, J.H. Kramers (ed.), Bibliotheca Geographorum Arabicorum II (Leiden, 1938-39), p. 105; cited and translated in J.F.P. Hopkins and N. Levtzion, Corpus of early Arabic sources for West African history (New York: Cambridge University Press 1981), pp. 50-51.

30. Norris, Saharan Saga and Myth (London: Oxford University Press 1972), p. 57.

31. Luqmān is generally considered by Muslim writers to have been an Ethiopian or Nubian slave who was proverbially wise. Najāshī was the Ethiopian king who gave shelter to the early Muslims fleeing Arabia. Bilāl was a freedman of Ethiopian descent who became the first muezzin (caller to prayer) in Islam. The quote is cited in the questions sent to Ahmad Bābā of Timbuktu by al-Jirārī, Mi 'rāj al-su 'ūd: Ahmad Bābā's Replies on Slavery, John Hunwick and Fatima Harrak (eds. and trans.) (Rabat: Université Mohammed V-Souissi, Institut des études africaines 2000), p. 17.

32. See for example, Surat al-Hujurāt (49: 13) 'O Mankind, We created your from a single (pair) of a male and a female, and made you into nations and tribes, that ye may know each other. Verily, the most honored of you in the sight of God is the most righteous of you.'

33. This is the impression I have from reading the highly empirical writing of the Andalusian geographer al-Bakrī. Kitāb al-masālik wa- l-mamālik. Baron William MacGuckin de Slane ed. and trans., Description de l'Afrique septentrionale (Paris: Librairie d'Amérique et d'Orient Adrien-Maisonneuve 
1965). A translated excerpt is in Levtzion and Hopkins, Corpus of early Arabic sources for West African history, pp. 63-87.

34. From Mas' 'ūd̄̄, Murūj al-dhahab; quoted in Lewis, Race and Color in Islam, p. 34.

35. Shams al-Dīn Muhammad b. Abī Tālib al-Dimashqīi, Nukhbat al-Dahr fì 'ajā'ib al-barr wa 'l-bahr, A. Mehren (ed.) (Leipzig: Harassowitz 1923), pp. 15-17; translated by John Hunwick, 'Arab views of Black Africans and Slavery' presented at conference 'Collective Degradation: Slavery and the Construction of Race', Yale University, November 2003, pp. 10-11; a slightly different translation is in Levtzion and Hopkins, Corpus of early Arabic sources for West African history, p. 205

36. For example, in Jāhiz's (ca. 776-869) Boast of the Blacks over the Whites (Fakhr al-sūdān 'alā albidān), he includes amongst the Blacks the inhabitants of India, Southeast Asia and China. Lewis, Race and Color in Islam, pp. 16-17. It is also important to note that the four broad regional terms used to label Africans were expanded upon in works of greater detail on particular regions. Arab geographers divided the people of the East African region into more groups than just the Zanj. See J. Spencer Trimingham, 'The Arab Geographers and the East African Coast', H. Neville Chittick and Robert Rotberg (eds.), East Africa and the Orient: Cultural Synthesis in Pre-Colonial Times (New York: Africana Pub. Co. 1975), pp. 115-146; L.-Marcel Devic, Le pays des Zendjs ou la côte orientale d'Afrique au Moyen-âge (Amsterdam: Oriental Press 1975).

37. This is according to 'Abd al-Rahmān al-Suyūtī, Raf 'sha'n al-hubshān. Safwān Dāwudī and Hassan 'Ubajī (eds.) (Jedda: Dar al-Qiblah Lil-Thaqafa al-Islamiya 1991), p. 33.

38. This was a common description of the coastal Zanj.

39. in Levtzion and Hopkins, Corpus of early Arabic sources for West African history, p. 15.

40. Norris, The Berber in Arabic Literature, pp. 33-39.

41. Ibid., p. 36

42. quoted in Ibid., pp. 39-40.

43. Norris, Saharan Saga and Myth, p. 31.

44. Norris, The Berber in Arabic Literature, pp. 40-43.

45. Ibn Battuta (note 2), p. 28.

46. Norris, Saharan Saga and Myth, pp. 28-29.

47. I know of two texts in Timbuktu that are devoted explicitly to providing useful excerpts from Ibn Khaldūn's History. They are written by Muhammad b. Ahmad b. Muhammad b. Habbata al-Ghallāwī, Centre de Documentation et de Recherche Historique Ahmad Baba, Timbuktu, Mali [hereafter CEDRAB] mss. 639, 4609.

48. Even if the constructions made by Southern Saharan scholars would have been at odds with Ibn Khaldūn's views. Norris, The Arab Conquest of the Western Sahara, pp. 13-14.

49. Ibn Khaldūn, The Muqaddima: An Introduction to History. vol.1. Franz Rosenthal (trans.) (New York: Princeton University Press 1967), pp. 169-70. Cited in Hunwick, 'Arab Views of Black Africans and Slavery', p. 8. It should be noted that elsewhere, Ibn Khaldūn seems to concur with the idea of Hamitic descent.

50. In Levtzion and Hopkins, Corpus of early Arabic sources for West African history, p. 321.

51. Ibid., p. 321.

52. Hunwick, 'Arab Views of Black Africans and Slavery', p. 17.

53. On this correspondence see E.M. Sartain, 'Jalal ad-Din As-Suyuti's relations with the people of Takrur', Journal of Semitic Studies 16,/2 (1971), pp. 193-98; idem, Jalāl al-dīn al-Suyūtī: Biography and background (Cambridge: Cambridge University Press 1975), pp. 50-51; Norris, The Tuaregs: their Islamic legacy and its Diffusion in the Sahel (Warminster: Aris \& Phillips 1975), pp. 45-47; Ould Cheikh, Eléments d'histoire de la Mauritanie (Nouakchott: Institut Mauritanien de recherche scientifique 1988), pp. 23-39.

54. Norris, The Arab Conquest of the Western Sahara, pp. 122-23; Hunwick, Sharì in Songhay: the Replies of al-Maghīlī to the Questions of Askia al-Hājj Muhammad (Oxford: Oxford University Press 1985), p. 43.

55. For a modern publication of the Raf', see note 37. The abridgement has also been published: Azhār al'urūsh fì akhbār al-hubūsh 'Abd Allāh 'Isā al-Ghazālī (ed.) (Kuwait: Markaz al-Makhtutat wa-alTurath wa-al-Watha'iq 1995). Al-Suyūtī also wrote several other works on related subjects such as the good qualities of slave girls, poems and sayings in praise of 'Blacks,' etc. On these different works by al-Suyūtī, see Saud H. al-Khathlan, 'A Critical Edition of Kitāb Raf' Sha'n al-hubshān by Jalāl al-dīn al-Suyūtī’ (Dissertation, University of St. Andrews, 1983), pp. 14-17, 26, 33-34.

56. Published as: Abū al-Faraj `Abd al-Rahmān b. al-Jawz̄̄, Tanwīr al-ghabash fì fadl al-sūdān wa-'l-habash Marzūq 'Alī Ibrāhīm ed. (Riyad: Dar al-Sharif 1998). 
57. Akbar Muhammad, 'The image of Africans in Arabic Literature: Some Unpublished Manuscripts', John Ralph Willis (ed.), Slaves and Slavery in Muslim Africa. Volume 1: Islam and the Ideology of Enslavement (London: Frank Cass 1985), p. 55. See also, Imran Hamza Alawiye, 'Ibn al-Jawzì's Apologia on behalf of the Black People and their Status in Islam: a Critical Edition and Translation of Kitāb Tanwīr al-Ghabash fī Fadl al-Sūdān wa-'l-habash', (Dissertation, University of London, 1985).

58. al-Suyūtī, Raf 'sha'n al-hubshān, pp. 37-49, 207-11; idem, Azhār al-'urūsh fì akhbār al-hubūsh, pp. 19-22.

59. I am not aware of any extant manuscript copies of this text in West Africa, although it was quoted in the writings of some Sahelian writers such as Ahmad Bābā as we will see below. On the large number of copies of the manuscript extant in libraries around the Middle East see, al-Khathlan (note 55), p. 44.

60. On the life of Ahmad Baba see Mahmoud Zouber, Ahmad Baba de Tombouctou (1556-1627) : sa vie et son ouvre (Paris: G.-P. Maisonneuve et Larose 1977).

61. The issue would become even more controversial when, in 1699, the Moroccan Sultan Mawlay Isma'il ordered the enslavement of the entire free Black population of Morocco so as to incorporate them into the royal army. See Chouki el Hamel, "Race", Slavery and Islam in Maghribi Mediterranean Thought', Journal of North African Studies $7 / 3$ (2002), pp. 29-52; Hunwick, 'Islamic Law and Polemics over Race and Slavery in North and West Africa (16th-19th century)', Shaun E. Marmon (ed.), Slavery in the Islamic Middle East (Princeton: M. Wiener 1999), pp. 52-59; Allan Meyers, 'Class, ethnicity and slavery: the origins of the Moroccan' abīd', International Journal of African Historical Studies 10 (1977), pp. 427-42; idem, 'Slave soldiers and state politics in early 'Alawī Morocco, 1668-1727', International Journal of African Historical Studies 16 (1983), pp. 39-48.

62. In more recent texts from Northern Mali he is referred to by the nisba given to him during his stay in North Africa - al-Sūdānī - which of course refers to the place of his origin but which also carries the racial identifier of 'Black.' His full name is: Ahmad Bābā bin Ahmad bin Ahmad bin 'Umar bin Muhammad `Aqīt.

63. Ahmad Bābā, Mi rāj al-sùūd, 27.

64. Ibid., pp. 24-26.

65. Ibid., p. 35.

66. Ibid., p. 32.

67. Ibid., p. 35; Hunwick, 'Islamic Law and Polemics over Race and Slavery in North and West Africa', p. 51.

68. Muhammad al-Sanūsī b. Ibrāhīm al-Jārimī, Tanbīh ahl al-tughyān `alā hurriyyat al-sūdān ['Drawing the Attention of Tyrannical Folk to the Free Status of the Blacks'], CEDRAB ms. 1575. See Hunwick's discussion of these texts in 'Islamic Law and Polemics over Race and Slavery in North and West Africa', p. 62.

69. On the historical details of this shift in power in the Niger Bend after the Moroccan invasion, see Michel Abitbol, Tombouctou et les Arma. De la conquête marocaine du Soudan nigérien en 1591 à l'hégémonie de l'empire peul du Maçina en 1853 (Paris: G.-P. Maisonneuve et Larose 1979); Elizabeth Hodgkin, 'Social and Political Relations on the Niger Bend in the Seventeenth century', (Dissertation, Birmingham University, 1987).

70. David Robinson, Chiefs and clerics: Abdul Bokar Kan and Futa Toro, 1853-1891 (Oxford: Clarendon Press 1975), pp. 10-12.

71. Stewart, 'Southern Saharan Scholarship and the Bilād al-sūdān', p. 77.

72. Colonial writers such as Paul Marty saw in the events of Shur Bubba a culmination of an ethnic conflict between indigenous Berber-speaking groups and hassanī Arabs, which resulted in Arab hegemony. See Etudes sur l'Islam et les tribus maures, les Brakna (Paris: E. Leroux 1921). Charles Stewart argued that the story of Shur Bubba was a foundation myth that provided a social charter for the complementary occupational and status distinction between 'warriors' and 'clerical' groups, that came to underlay the segmentary nature of Southern Saharan societies. In Stewart's view, very similar developments occurred all across the Southern Sahara in the second half of the seventeenth century, all of which constituted a larger Southern Saharan world whose religious specialists would play an important role in spreading a particular kind of Islamic practice throughout West Africa. See 'Southern Saharan Scholarship and the Bilād al-sūdān'. Others such as Abdel Wedoud ould Cheikh and Pierre Bonte have played down the importance of the seventeenth century as formative in the constitution of segmentary society and bìdān identity. See ould Cheikh, Eléments d'historie de la Mauritanie, pp. 63-67; 'Nomadisme, Islam et pouvoir politique dans la société maure pré-coloniale', pp. 830-982; Bonte, 'Tribus, fractions, et état: Les conflits de succession dans l'émirat de l'Adrar', Cahiers d'études africaines 22-24 (1987-88), pp. 489-516. Webb sees the seventeenth century as a period when an increase in frontier violence along the desert edge produced articulations 
of Black-White identity, of which the Wars of Shur Bubba are but the best-known example. See Desert Frontier, pp. 33-34.

73. Stewart, 'Southern Saharan Scholarship and the Bilād al-sūdān', pp. 78-81.

74. The dearth of local sources before the seventeenth century makes it extremely difficult to trace the importance of Islam in Southern Saharan identities. Certainly, sites of Islamic specialisation existed before the seventeenth century. Timbuktu was well known for its scholars, the most notable of which were Ahmad Baba and Muhammad Baghayogho (d. 1523-4).

75. In Levtzion and Hopkins, Corpus of early Arabic sources for West African history, p. 274.

76. See for example Wālid b. Khālunā's description of Nāsir al-Dīn as white-skinned, small, with curly hair, and a non-protruding nose; Amr al-wālì nāsir al-dīn, in Ismaël Hamet (ed. and trans.) Chroniques de la Mauritanie sénégalaise. Nacer Eddine (Paris: E. Leroux 1911), p. 165; (8 Arabic).

77. Raymond Taylor, 'Of Disciples and Sultans: Power, Authority and Society in the Nineteenth-Century Mauritanian Gebla', (Dissertation, University of Illinois at Urbana-Champaign, 1996), p. 4.

78. See for example, an undated manuscript entitled Ansāb al-`arab, written by somebody named Muhammad b. 'Abd Allah (CEDRAB mss. 1557), in which the origins of the Berbers, Copts and 'Blacks' from Hām are laid out. I make no claim to be able to offer any quantitative evidence for the number of manuscripts that make reference to writers such as Ibn Khaldūn. However, having spent the better part of two years working with the Arabic manuscripts held in Timbuktu, it is certainly my experience that it is not uncommon. In addition to the manuscripts cited in note 47, there is another one devoted entirely to extracts from Ibn Khaldūn and others on the origins of the 'Blacks.' (CEDRAB mss. 8625) Unfortunately, this is also an undated text and the first page is badly damaged.

79. Thomas Whitcomb, 'New Evidence on the Origins of the Kunta - I', Bulletin of SOAS38/1 (1975), p. 108. See below.

80. Ould Cheikh, 'La Tribu comme volonté et comme représentation: Le Facteur religieux dans l'organisation d'une tribu maure, Les Awlād Abyayri', Pierre Bonte, Edouard Conte, Constant Hamès, Ould Cheikh (eds.), Al-Ansāb: La Quête des Origines. Anthropologie historique de la société tribale arabe (Paris: Editions de la Maison des sciences de l'homme 1991), p. 230.

81. Ould Cheikh, 'Nomadisme, Islam et pouvoir politique dans la société maure pré-coloniale', p. 198-99.

82. Ibid., p. 202; Norris, The Arab Conquest of the Western Sahara, pp. 26-27.

83. In addition to the War of Shur Bubba, Mauritanian historical traditions speak of decisive Arab impositions of tribute on existing Berberophone populations in the fourteenth and fifteenth centuries. See Norris, The Arab Conquest of the Western Sahara, pp. 33-35.

84. Norris, The Arab Conquest of the Western Sahara, pp. 106-08. There are a number of traditions among the Iwillimmeden concerning Arab Muslim origins. Some of these seem to have more in common with zawāya/inesleman traditions than with the Arab hassānī lineage discussed here. Some of these different traditions are laid our in A. Richer, Les Oulliminden. Les Touareg du Niger (Région de Tombouctou-Gao) (Paris: E. Lerose 1924), pp. 49-56.

85. Shaykh Sidi Muhammad b. Ahmad b. Sulaymān, 'Letter to Commandant of Trarza, A.M. Théveniaut', in Hamet, Chroniques de la Mauritanie sénégalaise, p. 158.

86. This passage is repeated in a number of manuscript histories of Arawan. The passage is translated in Norris, The Arab Conquest of the Western Sahara, p. 82.

87. From a manuscript by an unknown author entitled Ta'rīkh ahl agād w-Arawān wa-karāmāt ba'd awliyā'-him (CEDRAB mss. 9197)

88. As is obvious from their name, the Kel Antessar claim descent from the Ansār of Madina and trace their migration into North Africa, the Central Sahara, and finally, to the Niger Bend. However, they also claim that their lineage connects to Ahmad ag Adda because of a marriage between his mother and a Kel Antessar named Ifna. As such, the Kel Antessar are able to claim a genealogy that ties them to the Ansār and to a local Saharan saint. See Norris, The Arab Conquest of the Western Sahara, p. 83.

89. Anonymous author of manuscript entitled Khabar al-sūq (CEDRAB mss. 4604)

90. J. Geneviére, 'Les Kounta et leurs activités commerciales', Bulletin de l'IFAN 12 (1950), pp. 1111-1127.

91. One of the best-known novices was the Mauritanian al-Shaykh Sidiyya b. al-Murkhtār b. al-Hayba who spent 16 years at the Kunta zawāya in the Azawad. On his life, see Stewart, Islam and Social Order in Mauritania (Oxford: Clarendon Press 1973), p. 34.

92. Charles-André Julien, History of North Africa. Tunisia, Algeria, Morocco. From the Arab Conquest to 1830, John Petrie (trans.) (London: Praeger 1970), p. 11.

93. A mistake in the text. The former name for Walata is Bīru. 
94. The Awraba were a Berber group in the northern Maghreb. The site of Bawwar is unknown. It may be a confusion with Kawār in the Central Sahara where 'Uqba b. Nāfi 'is said to have gone on a punitive expedition (see note 102). Batran thinks that B-W-R should read Būra or Būda which he equates with Tahuda in Touat. See Aziz A. Batran, The Qadiryya Brotherhood in West Africa and the Western Sahara: The Life and Times of Shaykh al-Mukhtar al-Kunti, 1729-1811 (Rabat: Université Mohammed V-Souissi, Institut des étude africaines 2001), p. 10. However, since it is mentioned after Takrūr, one assumes that the author intends to suggest that Bawwar and the Awraba were in the Southwestern Sahara or Sahel. See Thomas Whitcomb, 'The Origins and Emergence of the Tribe of Kunta: a contribution to the history of the Western Sahara between the Almoravid period and the seventeenth century', (Dissertation, University of London, 1978), pp. 58-59.

95. Sīdī Muhammad b. Sīdī al-Mukhtār al-Kuntī, al-Risāla al-Ghallāwiyya, in Whitcomb, 'The Origins and Emergence of the Tribe of Kunta', English translation, p. 44, Arabic text, p. 305; a similar passage is in Sīdī Muhammad b. Sīd̄̄ al-Mukhtār al-Kuntī, Kitāb al-tarā'if wa-'l-talā'id, vol. 2, Abadine ould Baba Ahmed (ed.) (Nouakchott: al-Ma‘had al-Mūrītānī lil-ba'th al-'ilmī 1994), p. 11.

96. Cited in Batran, The Qadiryya Brotherhood in West Africa and the Western Sahara, pp. 21-22.

97. There are other Kunta texts that provide details on other branches of the family. See Whitcomb, 'The Origins and Emergence of the tribe of Kunta', p. 56

98. On the Kunta in Walata, see Cleaveland, Becoming Walāta, pp. 147-153.

99. For Iwillimmeden traditions connecting them to 'Uqba, see Richer, Les Oulliminden, pp. 49-56.

100. Julien, History of North Africa, pp. 7-11.

101. Ibn 'Abd al-Hakam (d. 871) provides an account of this in his Futūh misr; translated in Levtzion and Hopkins, Corpus of early Arabic sources for West African history, pp. 12-13.

102. Elizabeth Savage, A Gateway to Hell, A Gateway to Paradise: The North African Response to the Arab Conquest (Princeton: Darwin Press 1997), pp. 73-75; idem., 'Berbers and Blacks: Ibadi Slave Traffic in Eighth-Century North Africa', Journal of African History 33/3 (1992), pp. 351368. For other views about this expedition and its connection to sub-Saharan Africa see Tadeusz Lewicki, Arabic external sources for the history of the south of the Sahara (London: Carzon Press 1974), pp. 19-20; Knut Vikør, 'The Early History of the Kawār Oasis: a Southern Border of the Maghrib or a Northern Border of the Sudan?', The Maghreb Review 12 (1987), pp. $78-83$.

103. Batran, The Qadiryya Brotherhood in West Africa and the Western Sahara, p. 11.

104. Ibid., p. 13.

105. Ibid., p. 13. This is mentioned in Ibn 'Abd al-Hakam' Futūh misr; translated in Levtzion and Hopkins, Corpus of early Arabic sources for West African history, p. 13.

106. This passage is translated by Norris, The Arab Conquest of the Western Sahara, p. 240.

107. Ibid., pp. $227-41$.

108. On these and other inconsistencies, see Hunwick, Sharī ‘ in Songhay, pp. 42-44.

109. The history of this jihād is fairly well known. The details of the attack on the 'Blacks' can be found in a local Arabic document published and translated in Hamet, Chroniques de la Mauritanie sénégalaise, pp. $175-178$.

110. This passages is from an undated anonymous document entitled Ta'rīkh arawān (CEDRAB mss. 8905), fl.2.

111. Sīdī Muhammad b. Sīdī al-Mukhtār al-Kuntī, al-Risāla al-Ghallāwiyya, in Whitcomb, 'The Origins and Emergence of the Tribe of Kunta', p. 314.

112. The term Arma is derived from the Arabic rumāh or 'riflemen' which was used to describe the invading Moroccan soldiers.

113. 'wa-sukkān tinbuktu akthar-hum asl-hum min al-bīdān, man nasala jaysh mawlāy ahmad al-dhahabī [Ahmad al-Mansūr]'. This manuscript has been published in Libya by al-Hādī al-Mabrūk al-Dālī; Ahmad Bul 'arāf al-Tiknī, Izālah al-rayb wa-'l-shakk wa-'l-tafrīt fì dhikr al-mu'lifìn min ahl al-takrūr wa-'l-sahrā' wa-ahl shinqūt (Benghazi: Dar al-kutub al-Wataniyya Banghazi 2000), p. 53.

114. Ibid., p. 54. For a less detailed, but similar local account of the identity of the Arma written more recently, see Ahmad Bābīr al-Arawānī, Jawāhir al-hisān fì akhbār al-sūdān. al-Hādī al-Mabrūk al-Dālī (ed.) (Benghazi: Dar al-kutub al-Wataniyya Banghazi 2001), p. 69. 
